\title{
Varietal response of strawberry to environmental conditions of Quetta (Balochistan) for runner production
}

Fazal Muhammad Bangulzai ${ }^{1 *}$, Naseer Ahmed ${ }^{1}$, Zakia Bibi ${ }^{1}$, Abdul Raziq ${ }^{1}$, Syed Muhammad Ishaq ${ }^{1}$, Abdul Sattar Khetran ${ }^{1}$, Rehmatullah Khetran ${ }^{1}$ and Lal Bakhsh ${ }^{2}$

1. Agriculture Research Institute (A.R.I) Sariab Quetta, Balochistan-Pakistan

2. Directorate of Agriculture Research, Usta Muhammad, Balochistan-Pakistan

*Corresponding author's email: fazalbangulzai786@gmail.com

Citation

Fazal Muhammad Bangulzai, Naseer Ahmed, Zakia Bibi, Abdul Raziq, Syed Muhammad Ishaq, Abdul Sattar Khetran, Rehmatullah Khetran and Lal Bakhsh. Varietal response of strawberry to environmental conditions of Quetta (Balochistan) for runner production. Pure and Applied Biology. Vol. 8, Issue 1, pp42-49.

http://dx.doi.org/10.19045/bspab.2018.700162

\begin{tabular}{llll}
\hline \hline Received: 09/08/2018 & Revised: 01/10/2018 & Accepted: 03/10/2018 & Online First: 05/10/2018 \\
\hline \hline
\end{tabular}

\section{Abstract}

Five strawberry varieties (Pochanta, Tuft, Tioga, Aliso and Red-berlet) were tested for consecutive two years (2016 and 2017) Experiment laid out at experimental and demonstration orchard, Agriculture Research Institute, Sariab Quetta to develop the most promising cultivar for runner production under the environmental condition of Quetta (Balochistan). The experiment laid out in a four replicated randomized complete block design (RCBD). The results revealed that strawberry varieties differed significantly $(\mathrm{P}<0.05)$ for survival rate, runners plant ${ }^{-1}$ and runner yield; while effect of season and interactive effect of variety $\times$ season was insignificant $(\mathrm{P}>0.05)$. The two years mean data indicated that Red-berlet variety showed superiority over rest of the tested varieties with highest values for survival rate (98.38\%), runners plant ${ }^{-1}$ (35.79) and runner yield plot $^{-1}(860.3)$. Apart from the most superior performance of variety Red-berlet, Tioga, Aliso and Tuft also showed good average performance, but Pochanta remained the least under agro-ecological conditions of Quetta (Balochistan). Therefore, the performance of tested strawberry varieties ranked as Red-berlet $>$ Tioga $>$ Aliso $>$ Tuft $>$ Pochanta.

Keywords: Environmental conditions; Runners plant $^{-1}$; Runner yield Strawberry; Varieties

\section{Introduction}

Strawberry (Fragaria ananassa) belongs to family Rosaceae is a perennial herbaceous plant with red Fruits, is native to mountainous tropical and temperate region. The name is derived from two old English words "strew" meaning "Straw" and beige meaning "berry" [1]. As nutritionally strawberry is a rich source of vitamin $\mathrm{C}$, provides more vitamin $\mathrm{C}$ than orange, contains fiber and low calorie carbohydrate [2]. Due to favorable climatic and soil condition strawberry is successfully cultivating in upper area of Sindh province, where total area under strawberry cultivation is about 236 hectares [3]. In KPK strawberry is cultivated in lower altitude in the month of November and it produces fruit in the month 
of April and May [4]. For enjoying the delicious strawberry, sliced strawberries may be added in green salad; strawberries can be mixed with Orange juice, lemon juice, maple syrup and added with yogurt. Moreover chopped strawberries may be placed on toast [5-8].

.Strawberry is recognized as appetizing and nutritive fruit with enormous dietetic value and potential source of vitamin, carbohydrates, fats and proteins for humans. The Strawberry is not only consumed in fresh form, but it is also utilized for processed forms of jam, jellies and squashes around the year in Pakistan [9, 10]. High yielding varieties has been the basic requirement for high strawberry production and expanding the consumer market locally as well as to attract export demand. Hence, it is need of the time to plant high yielding and high fruit quality varieties, not only to maximize yield per unit area but also to offer fruits of a variety of colours and taste [11-15]. The common cultivars grown in Islamabad are sweet Charlie, tuft, Pochanta, chandler, and cruz. For Swat chandler, corona, gorilla and honeyo are recommended. The strawberry is successfully grown in Swat, Charsada, Abatabad, Mansera, Peshawar, Haripur,Mardan, Gujrat, Chakwal, Jhelum, Multan, Sialkot and Karachi [16].

In Pakistan, total cost of production is about Rs. 100,000 per acre while revenue is Rs. 200.000 per acre and area of cultivation is 78 hectares with 274 tons annual production [3].The average fruit yield per acre is very low as compare to other strawberry growing countries due to lack of research, defective agronomic practices and lack of market and economic value. [17].

\section{Materials and methods}

The aim of this study was to investigate the best cultivar of strawberry for runner production under the environmental condition of Quetta. The experiment was conducted for consecutive two years (2016 and 2017) at experimental and demonstration orchard of Directorate Agriculture Research ARI, Sariab Quetta using five strawberry varieties which included (i) Pochanta, (ii) Tuft, (iii) Tioga, (iv) Aliso and (v) Redberlet. The experiment laid out in a four replicated randomized complete block design (RCBD). Whole plot was ploughed and leveled for even distribution of irrigation water for conducting experiment. And the plot was divided in four replications and each replication was divided in five sub-plots measuring $3 \mathrm{mx} 3 \mathrm{~m}\left(9 \mathrm{~m}^{2}\right)$. Thereafter, $1 \mathrm{~kg}$ TSP + 5 kg FYM were applied per sub-plot. Before transplantation of Strawberry runners were treated with fungicide and then runners were transplanted in rows at $60 \mathrm{~cm} \times 60 \mathrm{~cm}$ plant to plant and row to row distance. After translating, the plots were irrigated immediately. Throughout growing season all cultural practices i.e. weeding hoeing etc. were carried out. When the plants were attained establishment, five normal looking plants were randomly selected in each subplot and the observations were recorded on the survival percentage, number of runners plant $^{-1}$ and yield of runners per plot at the Field. The two years collected data were statistically analyzed using ANOVA to assess the significance of varietal and seasonal effect on the crop performance. The LSD test was employed to examine the significance of differences between varieties and seasons.

\section{Results and discussion Survival rate $(\%)$}

The survival rate of strawberry varieties Pochanta, Tuft, Tioga, Aliso and Red-berlet was compared for two consecutive years and the data (Figure 1, 2) indicate that the survival rate varied significantly for varieties $(\mathrm{F}=4.69 ; \quad \mathrm{DF}=4 / 39 ; \quad \mathrm{P}<0.01)$ and nonsignificant for seasons/years $(\mathrm{F}=2.48$; $\mathrm{DF}=1 / 39 ; \mathrm{P}>0.05)$ as well as for treatment interaction $(\mathrm{F}=0.08 ; \mathrm{DF}=4 / 39 ; \mathrm{P}>0.05)$. The two years average survival rate was 
maximum (98.38\%) in strawberry variety Red-berlet, followed by an equal survival rate of 95.75 percent in varieties Aliso and Tioga; the survival rate decreased to 94.12 percent in case of variety Tuft; while the lowest survival rate $(91.25 \%)$ was examined in case of variety Pochanta. Varieties Aliso and Tioga showed similarity for survival rate; but all other varieties showed significant $(\mathrm{P}<0.05)$ varieties for their survival percentage. Hence, under agro-ecological conditions of Quetta (Balochistan), varieties attained survival rate as Redberlet $>$ Aliso/Tioga $>$ Tuft $>$ Pochanta .

The interactive effect of varieties $\times$ seasons showed was ( $\mathrm{P}>0.05)$; however, all the varieties showed higher survival rate in the second year as compared to first year of experiment. Red-berlet showed 98.75 and
98.00 percent survival; followed by Tioga (96.5 and 95.0\%), Aliso (96.5 and 95.0\%), Tuft (95.25 and 93.0\%), Pochanta (92.5 and $90.0 \%$ ) in the years 2017 and 2016, respectively. Higher survival in the second might be associated with the improved management on the basis of first year experiment. These results are in agreement with those of Hancock and Simpson [8] who reported varied seed viability and seedling growth in strawberry varieties developed under diversified climatic conditions Heideet al. [9] reported that varieties originated in variable climates might differ in emergence and development. Similar results have also been reported by Josuttis et al. [18] who found variable seedling survivability and seedling emergence in strawberry varieties originated in different ecological zones.

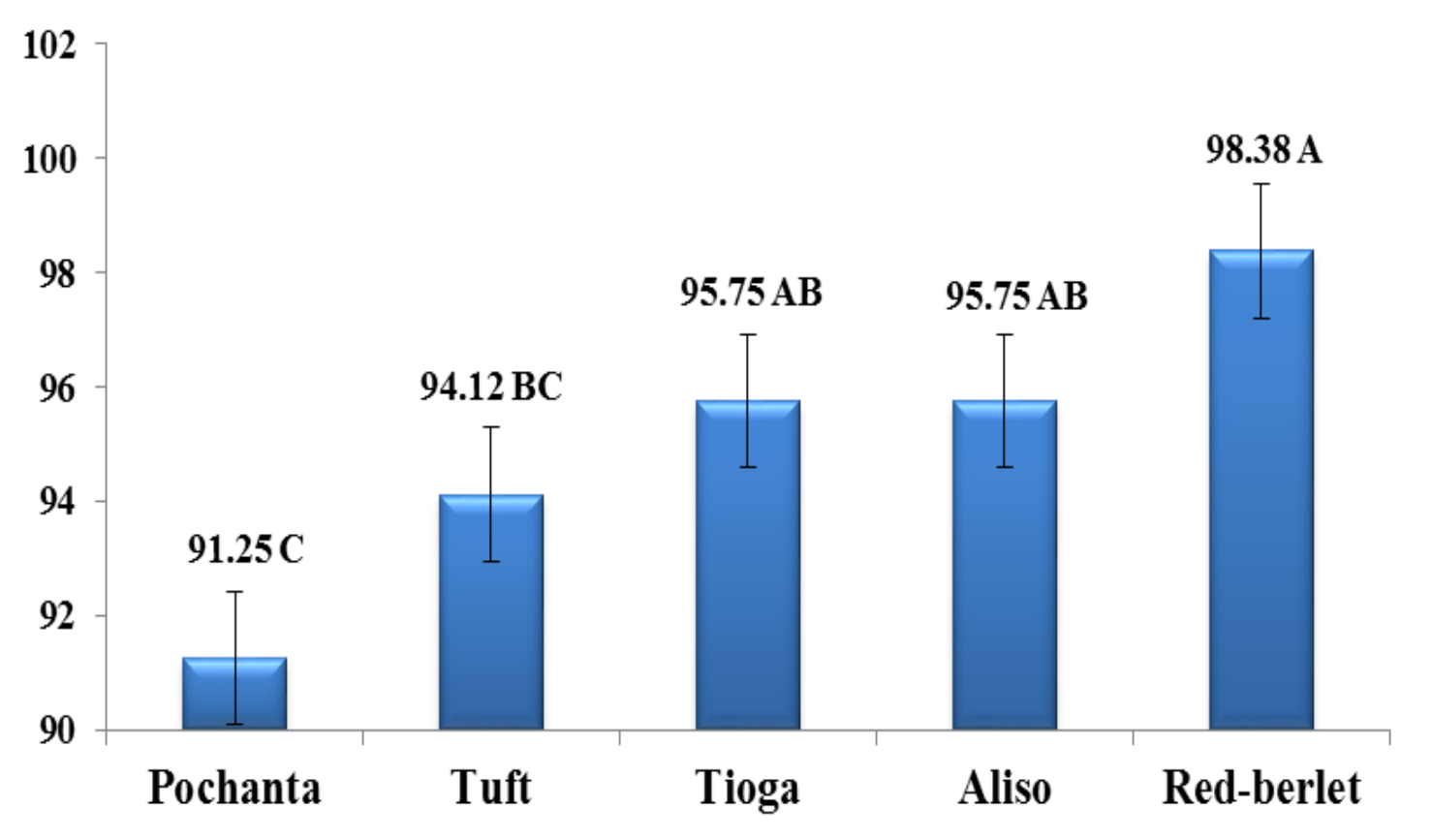

Figure 1. Two years average survival (\%) of strawberry varieties under environmental conditions of Quetta (Balochistan) 


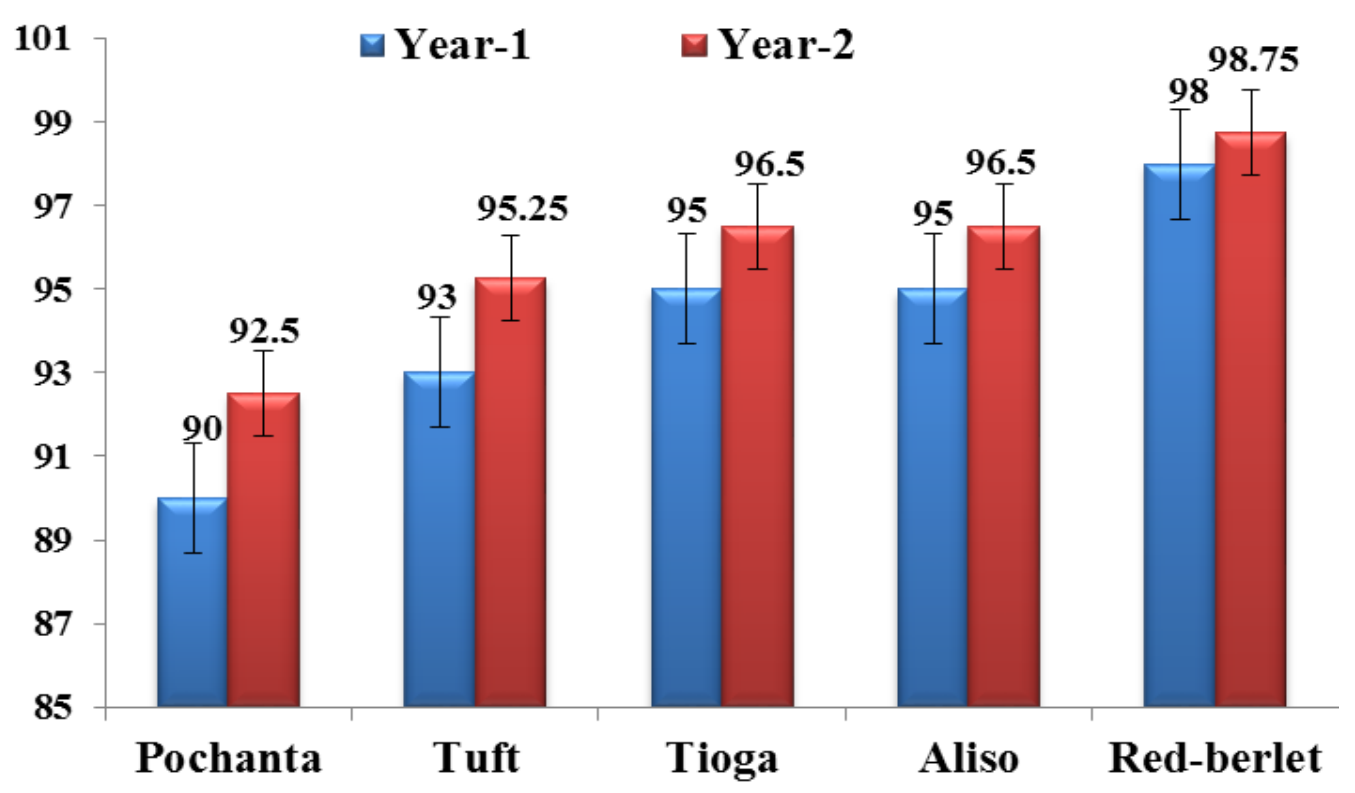

Figure 2. Interactive effect of varieties and seasons on average survival percentage of strawberry seedlings

\section{Number of runners plant $\mathbf{t}^{-1}$}

The number of runners plant ${ }^{-1}$ produced by Pochanta, Tuft, Tioga, Aliso and Red-berlet strawberry varieties was recorded for two years period (2016 and 2017) and the data (Figure 3,4) demonstrated that the varietal effect on runners plant ${ }^{-1}$ was significant $(\mathrm{F}=24.88 ; \mathrm{DF}=4 / 39 ; \mathrm{P}<0.01)$ and similarly the effect of seasons/years $(\mathrm{F}=4.14$; $\mathrm{DF}=1 / 39 ; \quad \mathrm{P}=0.05)$; while insignificant $(\mathrm{P}>0.05)$ for treatment interaction $(\mathrm{F}=0.01$; $\mathrm{DF}=4 / 39 ; \quad \mathrm{P}>0.05)$. Two years average number of runners plant ${ }^{-1}$ was highest (35.79) in variety Red-berlet, followed by Tioga, Aliso and Tuft with 32.46, 31.44 and 29.91 runners plant $^{-1}$, respectively. Pochanta strawberry variety produced least number of runners plant ${ }^{-1}$ on average. Variety Redbserlet showed most superior performance in regards to runners plant ${ }^{-1}$, while Tioga, Aliso and Tuft also showed good average performance, but Pochanta remained the least. Therefore, the performance of tested strawberry varieties ranked as Redberlet $>$ Tioga $>$ Aliso $>$ Tuft $>$ Pochanta.
The variety $\times$ year interactive effect on runners plant ${ }^{-1}$ was insignificant $(\mathrm{P}>0.05)$; however, the overall performance of entire varietal group was better in the second year of experiment compared to first year. Redberlet produced 36.57 and 35.0runners plant ${ }^{-}$ 1; followed by Tioga (33.18 and 31.75), Aliso (32.13 and 30.75), Tuft (30.56 and 29.285), Pochanta (26.12 and 25.0) in the years 2017 and 2016, respectively. This variation in the varietal behavior of strawberry varieties might be associated with the genetic makeup of parental material of these varieties, because interactive effect of seasons and varieties was insignificant $(\mathrm{P}>0.05)$. Koskela et al. [11] suggested that strawberry varieties perform potentially under the environments similar to their origin; while Koskela et al. [12] experienced that strawberry varieties cannot exceed their potential performance and such variation may be according to the natural potential of these varieties. Lieten [14] indicated that before sowing exotic varieties of strawberry, their genetic potential 
and environmental suitability must be taken into consideration.

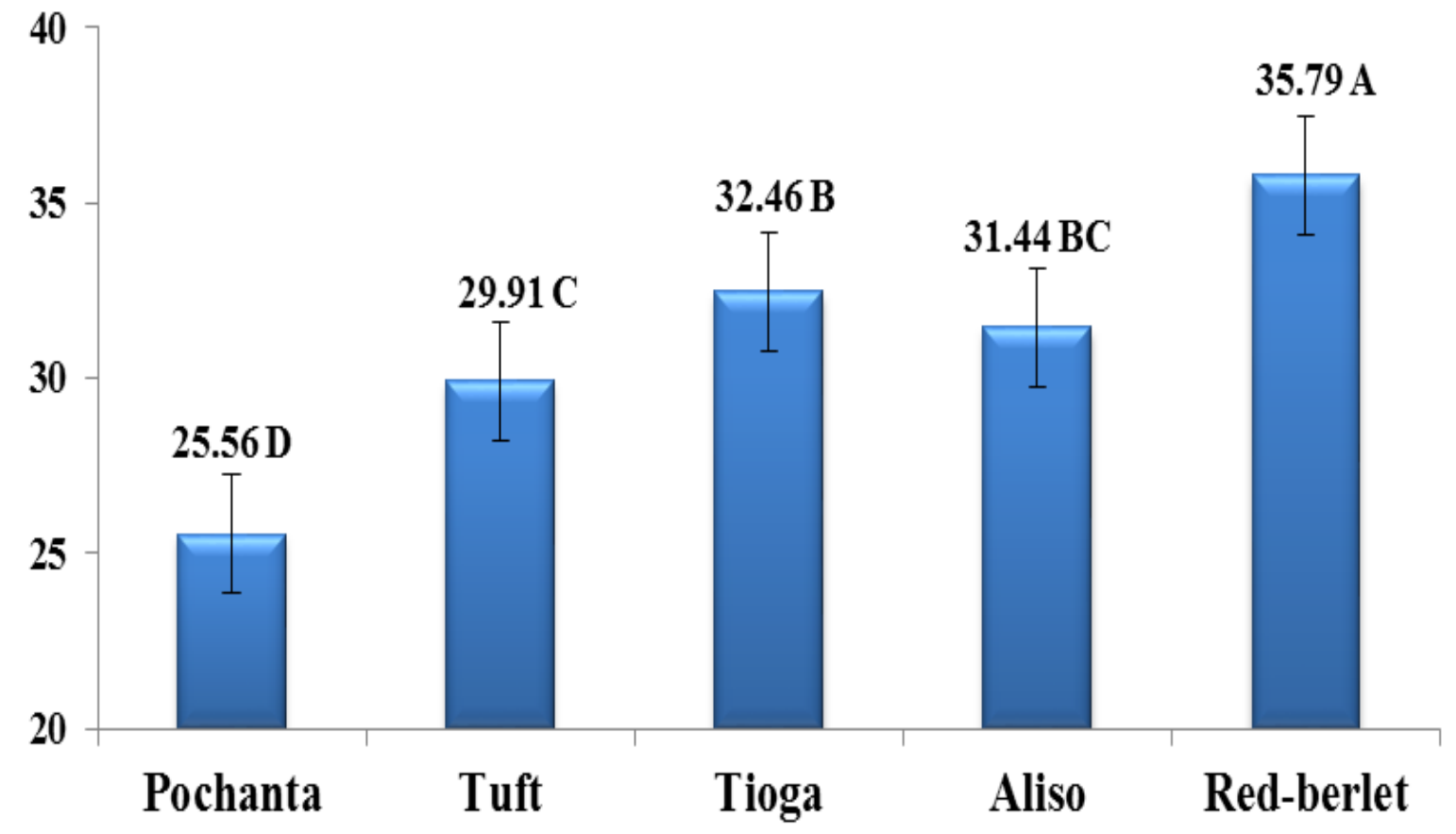

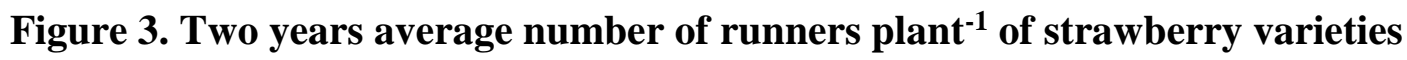

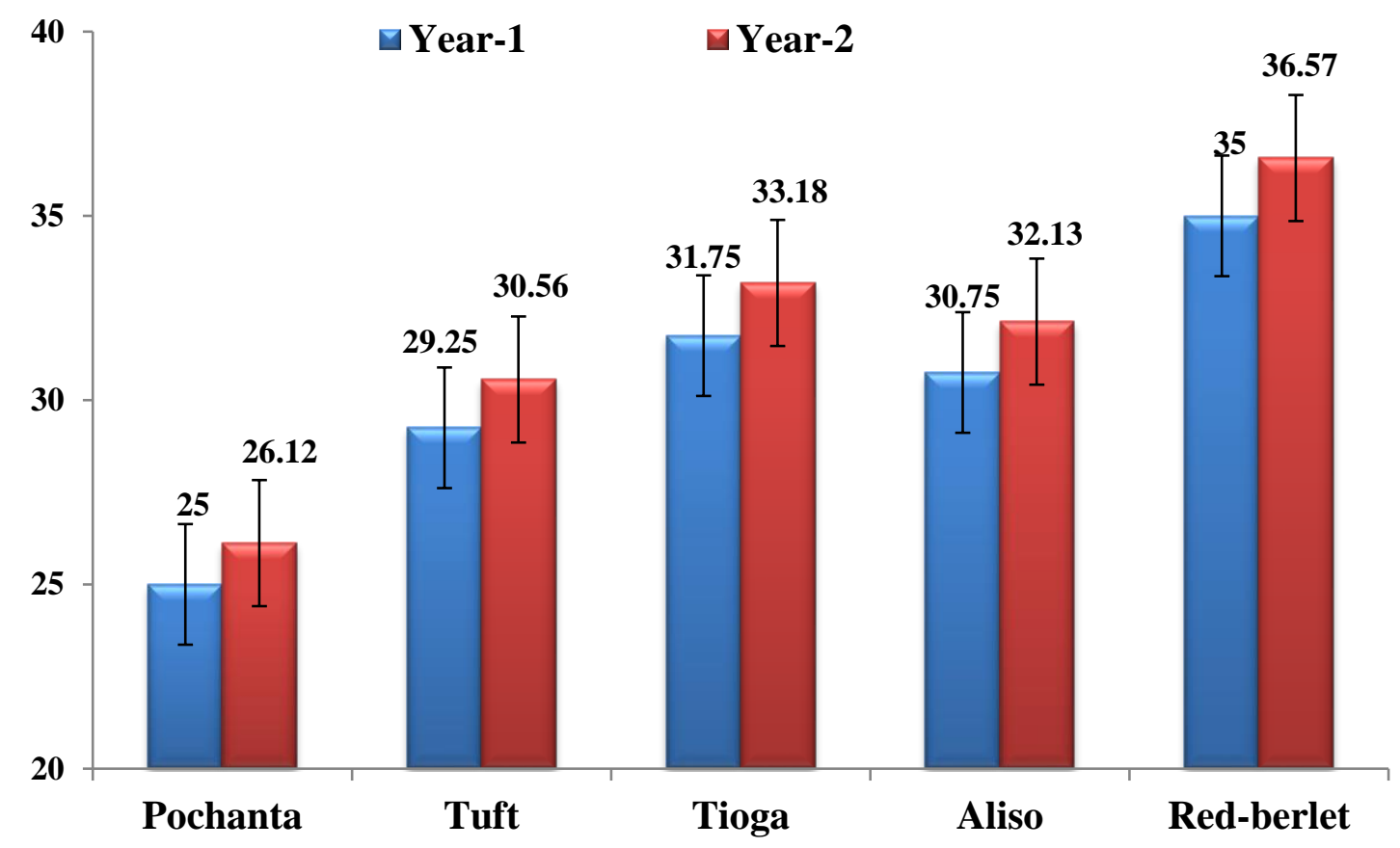

Figure 4. Interactive effect of strawberry varieties and seasons on average number of runners plant ${ }^{-1}$ 


\section{Runner yield plot ${ }^{-1}$}

The runner yield plot $^{-1}$ achieved from the strawberry varieties Pochanta, Tuft, Tioga, Aliso and Red-berlet was documented (2016 and 2017) and the data (Figure 5, 6) revealed that the varietal effect on runner yield plot $^{-1}$ was significant $(\mathrm{F}=16.99 ; \mathrm{DF}=4 / 39 ; \mathrm{P}<0.01)$ and insignificant $(\mathrm{P}>0.05)$ for seasons/years $(\mathrm{F}=0.81 ; \mathrm{DF}=1 / 39 ; \mathrm{P}>0.05)$ as well as for interaction between varieties and seasons $(\mathrm{F}=0.01 ; \quad \mathrm{DF}=4 / 39 ; \quad \mathrm{P}>0.05)$. The average runner yield plot $^{-1}$ was maximum (860.3) in variety Red-berlet, followed by Tioga, Aliso and Tuft with average runner yield of 718.36 , 699.53 and 623.22 runners plot ${ }^{-1}$ respectively. Pochanta strawberry variety produced least runner yield plot $^{-1}$ on average (834.7). It is evident from the results that variety Redberlet showed most promising runner yield plot $^{-1}$, while Tioga, Aliso and Tuft also showed encouraging yield performance. However, Pochanta remained relatively poor in overall and yield performance. On the basis of runner yield the tested varieties performance ranked as Redberlet $>$ Tioga $>$ Aliso $>$ Tuft $>$ Pochanta. The variety $\times$ season interactive effect on runner yield was insignificant $(\mathrm{P}>0.05)$; but the yield performance of all the tested varieties was higher in the second year of study. Red-berlet variety produced yield of 875.09 and 845.5 runners plot ${ }^{-1}$; followed by Tioga (730.71 and 706), Aliso (711.56 and 687.5), Tuft (633.94 and 612.5), Pochanta (543.89 and 525.5) in the years 2017 and 2016, respectively. This deviation in varietal response to yield might be related to genetic makeup of parental material of these varieties. Koskelaet al. (2016) reported that varieties generally produce runner yields according to their yield potential under certain environmental conditions; and the yield may vary under changed environments. In a similar investigation, Lieten [15] argued that the varietal potential may be influenced by the environmental conditions. Alsheikh et al. [5], Darnell et al. [6] and Eikemo et al. [7] also have reported results in their studies similar to the findings of the present research. Eikemo and Stensvand [8] have linked the yield trend of strawberry varieties to their genetic potential and environmental conditions.

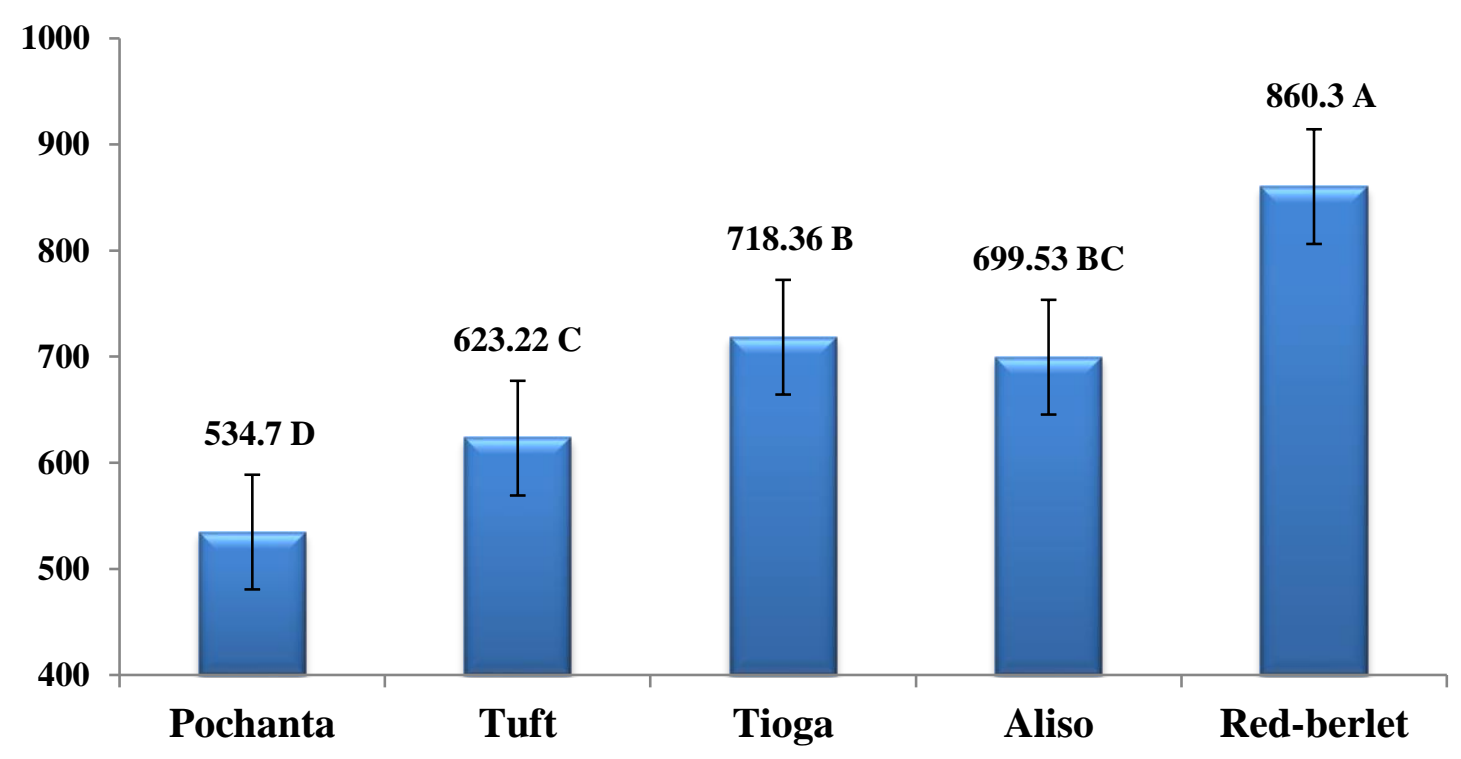

Figure 5. Two years average runner yield/plot of strawberry varieties under environmental conditions of Quetta (Balochistan) 


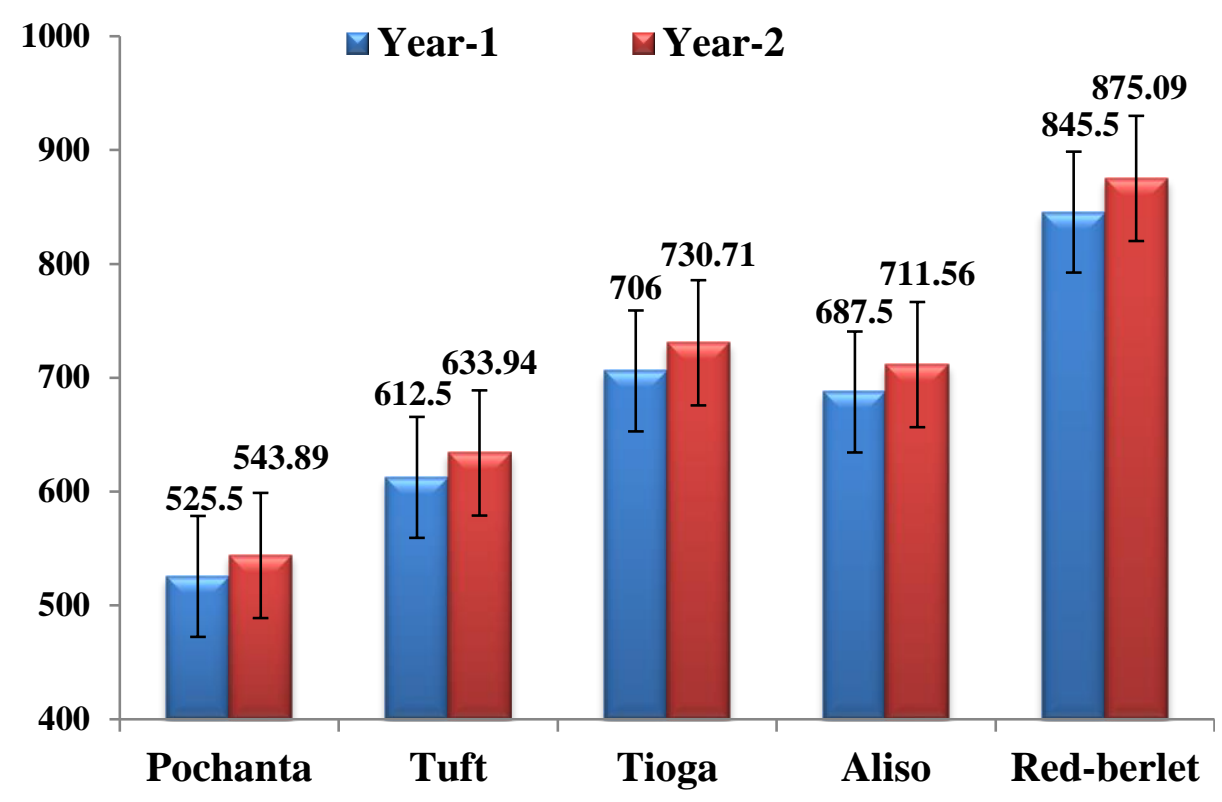

Figure 6. Interactive effect of varieties and seasons on average runner yield/plot of strawberry

\section{Conclusions}

It was concluded that strawberry variety Redberlet showed most superior performance under agro-ecological conditions of Quetta (Balochistan), followed by Tioga, Aliso and Tuft; while Pochanta remained the least. Therefore, the performance of tested strawberry varieties ranked as Redberlet $>$ Tioga $>$ Aliso $>$ Tuft $>$ Pochanta.

\section{Authors' contributions}

Conceived and designed the experiments: FM Bangulzai \& AS Khetran, Performed the experiments: FM Bangulzai \& SM Ishaq, Analyzed the data: N Ahmed, Contributed reagents/materials/analysis tools: $\mathrm{Z}$ Bibi, $\mathrm{L}$ Bakhsh, A Raziq \& R Khetran, Wrote the paper: FM Bangulzai \& Z Bibi.

\section{References}

1. Parveen S, Din A, Asghar M, Khan MR $\&$ Nadeem M (2012). Value addition in strawberry: a tool for long term storagea review. Pak J Frui Sci 22(4): 206-208.

2. Ayub M, Javidullah A, Muhammad \& Zeb A (2010). Evaluation of strawberry juice preserved with chemical preservatives at refrigeration temperature. Inter J Nutr Metabol 2 (2): 027-0325.

3. Khan MH (2014). Importance of strawberry in Pakistan. Dawn Newspaper. pp 5.

4. Afridi GS, Ishaq M \& Ahmad S (2009). Cost and revenue analysis of strawberry production in the sub-tropical areas of NWFP, Pakistan. Pak J of Life Sci 7(1): 59-65.

5. Alsheikh M, Sween R, Nes A \& Gullord M (2009). Strawberry breeding in Norway: Progress and future: Inter Soci for Horti Sci (ISHS) Leuven, Belgium pp 499-502.

6. Darnell RL, Cantliffe DJ, Durner EF, Poling EB \& Maas JL (2002). Recent advances in strawberry plug transplant technology. Hort Tech 12(4): 545-550.

7. Eikemo H, Stensvand A \& Tronsmo AM (2000). Evaluation of methods of screening strawberry cultivars for resistance to crown rot caused by Phytophthora cactorum. Annals of Applied Bio 137(3): 237-244. 
8. Eikemo H \& Stensvand A (2015). Resistance of strawberry genotypes to leather rot and crown rot caused by Phytophthora cactorum. Euro $J$ of $P$ Patho 143(2): 407-413.

9. Hancock J \& Simpson D (1995). Methods of extending the strawberry season in Europe. Hort Tech 5(4): 286290.

10. Heide OM, Stavang JA \& Sønsteby A (2013). Physiology and genetics of flowering in cultivated and wild strawberries - a review. The J of Hort Sci \& Biotech 88(1): 1-18.

11. Koskela E, Mohu K, Albani MC, Kurokura T, Rantanen M, Sargent DJ, Battey NH, Coupland G, Elomaa P \& Hytönen T (2012). Mutation in terminal flower reverses the photoperiodic requirement for flowering in the wild strawberry, Fragaria vesca. P Physio 159: 1043-1054.

12. Koskela EA, Sønsteby A, Flachowsky H, Heide OM, Hanke MV, Elomaa P \& Hytönen T (2016). Terminal flower is a breeding target for a novel ever bearing trait and tailored flowering responses in cultivated strawberry (Fragaria $x$ ananassa Duch.). P Biotech. J pp 1-10.

13. Lieten P. (2002). The use of cold stored plant material in Central Europe. Acta Hort 567: 553-560.

14. Lieten P (2013). Advances in strawberry substrate culture during the last twenty years in the Netherlands and Belgium. Int J of Fru Sci 13(1-2): 84-90.

15. Lieten P (2014). The Strawberry Nursery Industry in the Netherlands: an Update. Acta Hort 1049: 99-106.

16. Aslam M \& Rasool S (2012). Potential of strawberry's export from Pakistan. Pak J F Sci 22(4): 206-207.

17. Abbas S (2013). Benefits and variety of strawberry in Pakistan. Punjab (Pakistan)Agribusiness.http://w ww.agribusiness.com.pk/benefits-andvariety-of-strawberry-in-pakistan/.

18. Josuttis M, Carlen C, Crespo P, Nestby $\mathrm{R}$, Toldam-Andersen $\mathrm{T}$, Dietrich $\mathrm{H}$ \& Krüger E (2012). A comparison of bioactive compounds of strawberry fruit from Europe affected by genotype and latitude. J of Berry Res 2(2): 73-95. 